\title{
Temporal relationships between hormonal concentrations and the electrical resistance of the vaginal tract of blue foxes (Alopex lagopus) at pro-oestrus and oestrus
}

\author{
O. M. Møller*, M. Mondain-Monval†, A. Smith*, E. Metzger* and \\ R. Schollert
}

*Department of Animal Husbandry and Genetics, The Norwegian College of Veterinary Medicine, Postbox 8146 Dep., Oslo, Norway, and †Fondation de Recherche en Hormonologie, 67 Bd Pasteur, 94260 Fresnes, France

\begin{abstract}
Summary. During pro-oestrus, baseline LH concentrations for 9 vixens (pooled data) ranged from 0.8 to $5.3 \mathrm{ng} / \mathrm{ml}$. In each vixen, baseline levels were interrupted by elevations of $\mathrm{LH}$ ranging from $3 \cdot 1$ to $10.4 \mathrm{ng} / \mathrm{ml}$. A major preovulatory LH surge was detected in all the vixens. The $\mathrm{LH}$ peak ranged from 13.5 to $73.0 \mathrm{ng} / \mathrm{ml}$ with an average of $27.8 \pm 18.8$ (s.d.) $\mathrm{ng} / \mathrm{ml}$. Plasma LH concentrations declined to a basal level of $1 \cdot 3 \pm$ $1.0 \mathrm{ng} / \mathrm{ml}$ within $48 \mathrm{~h}$ of the peak value. The duration of the LH surge was $1-3$ days. The LH peak occurred 1 or 2 days before any sexual receptivity was observed. All the vixens were mated twice $2-5$ days after the $\mathrm{LH}$ peak; 8 conceived. Plasma concentrations of oestradiol- $17 \beta$ increased gradually during the last 6-7 days before oestrus and reached maximum values $(124-373 \mathrm{pg} / \mathrm{ml})$ at the time of the preovulatory $\mathrm{LH}$ peak. The first significant increase in plasma progesterone concentration occurred simultaneously with the LH peak. During oestrus (normally 3-5 days), progesterone levels rose steeply, attaining a mean concentration of $57.0 \pm 17.5 \mathrm{ng} / \mathrm{ml}$ when the vixens went out of heat. Androstenedione and testosterone values changed similarly, both increasing at the beginning of pro-oestrus and reaching maximum values $(805-1879 \mathrm{pg} / \mathrm{ml}$ and $328-501$ $\mathrm{pg} / \mathrm{ml}$ respectively) 1 day before to 1 day after the oestradiol-17 $\beta$ peak.

The electrical resistance of the vaginal tract increased rapidly during the last $2-3$ days of pro-oestrus, reaching a maximum value $(300-640 \Omega) \sim 2$ days after the oestradiol-17 $\beta$ peak that corresponded with the onset of sexual receptivity. Towards the end of oestrus, the values fell to 100-200 $\Omega$.
\end{abstract}

\section{Introduction}

Data on the reproductive physiology and endocrinology of the fox are scarce, and the available information is limited to the ovarian steroid hormones in peripheral plasma (Møller, 1973, 1974a, b; Mondain-Monval, Dutourné, Bonnin, Canivenc \& Scholler, 1977; Bonnin, Mondain-Monval \& Dutourné, 1978; Mondain-Monval, Bonnin, Scholler \& Canivenc, 1979; Møller, Aursjø \& Sjaastad, 1980). There appears to be no information for these furbearing animals on the changes in plasma concentrations of luteinizing hormone (LH) during pro-oestrus and oestrus, which take place once a year, usually in March and April. In the red fox (Vulpes vulpes), preliminary results have shown that plasma LH levels fluctuate throughout the year and particularly at the end of anoestrus from November to February, but daily variations around oestrus have not been investigated (Mondain-Monval, Bonnin, Canivenc \& Scholler, 1981). 
In the present paper, we have examined the sequence of hormonal events leading to oestrus, ovulation and the formation of corpora lutea in the blue fox. The electrical resistance of the vaginal tract is known to alter dramatically during the oestrous period (Møller \& Frøysedal, 1980; Møller, 1980) and we also attempted to correlate the data on hormonal events with the data on electrical resistance at the onset of oestrous behaviour and mating.

\section{Materials and Methods}

\section{Animals}

Blue fox vixens, $2-5$ years old, were used. The 9 vixens were individually housed under natural conditions of daylength and temperature before and during the investigation on the Research Farm for Furbearing Animals, Heggedal, Norway. They were given a ration of standard Norwegian wet feed and water ad libitum.

The animals were examined twice weekly in February and March for signs of pro-oestrus (usually 20-40 days before oestrus). Early pro-oestrus was defined as the period of onset of vulval swelling, while pro-oestrus proper was defined as the period of marked vulval swelling 5-10 days before oestrus. On each day of late pro-oestrus, i.e. when vulval swelling was near maximum, each vixen was checked for behavioural oestrus. The criterion for a vixen in oestrus was that the vixen allowed the male to mount and initiate coitus.

Evaluation of vulval swelling was used to determine the optimal day for the first mating in each vixen. Empirical observations have shown that the first mating should be carried out immediately after vulval swelling begins to subside and becomes paler.

Oestrus usually lasted for 3-5 days, matings being allowed twice at $48-\mathrm{h}$ intervals. The vixens were mated between 29 March and 9 April.

\section{Collection of blood}

Blood samples $(5-10 \mathrm{ml})$ were collected 3 times weekly during early pro-oestrus from the cephalic vein into heparinized tubes. The animals were sampled daily during late pro-oestrus and oestrus. Plasma was separated by centrifugation and stored at $-20^{\circ} \mathrm{C}$ until assay.

\section{Measurement of vaginal electrical resistance}

The electrical resistance of the vaginal tract was measured daily around oestrus using a modified ohmmeter developed by Metzger, Freytag \& Leidl (1972). The vaginal probe of the apparatus was $10 \mathrm{~mm}$ in diameter and equipped with two 4-mm wide metallic ring electrodes, one 8 $\mathrm{mm}$ and one $16 \mathrm{~mm}$ from the end of the probe. The probe was inserted up to the cervix when measurements were performed.

\section{Hormone assays}

$L H$. Plasma LH concentrations were measured by a modification of the double-antibody radioimmunoassay (RIA) of Nett et al. (1975) described and validated for the red fox by MondainMonval et al. (1981, 1984). This assay utilized ovine LH (No. 15) antiserum as the first antibody, a purified canine LH fraction (LER-1685-1) as a reference standard and ovine LH (LER-1056-C2) as labelled hormone. Values are expressed in terms of ng LER-1685-1/ml plasma, and pooled values as mean \pm s.d.

The validity of using canine RIA materials for measuring LH concentrations in the blue fox was tested by comparing the dose-response curves obtained with various quantities of blue fox plasma with curves from canine reference preparations. Serial dilutions with assay buffer of blue fox 
plasma containing high quantities of $\mathrm{LH}$ gave dose-response curves which were essentially parallel to the canine LH standard curve (Text-fig. 1). The inter-assay and intra-assay coefficients of variation were $10.3 \%(n=15)$ and $7 \cdot 3 \%(n=60)$ at a level of 1.6 and $1.8 \mathrm{ng} / \mathrm{ml}$ respectively. Minimum assay sensitivity was $0.4 \mathrm{ng} / \mathrm{ml}$.

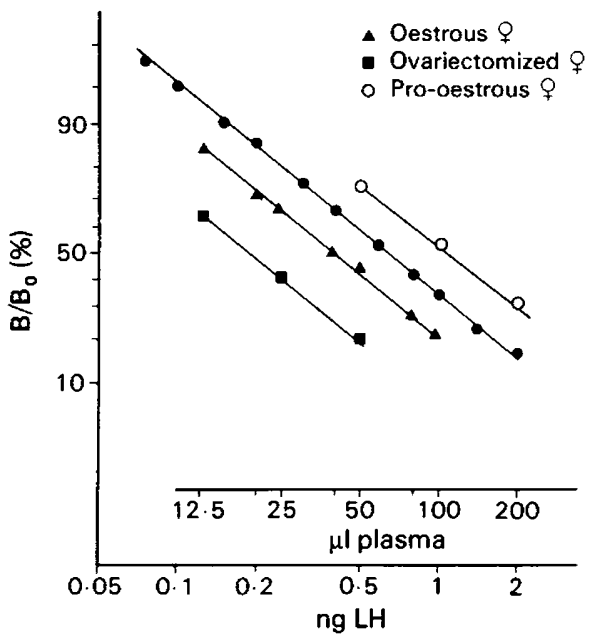

Text-fig. 1. Dose-response curves for dilutions of fox plasma samples in the LH radioimmunoassay. Standard curve for canine LH (LER 1685-1). B, amount of ${ }^{125}$ I-labelled $\mathrm{LH}$ bound in the presence of hormone; $\mathrm{B}_{0}$, amount of ${ }^{125}$ I-labelled LH bound in the absence of unlabelled hormone.

Steroids. Radioimmunoassays were used to measure steroid hormone concentrations.

Oestradiol-17 $\beta$ and progesterone values were determined from the same plasma samples $(1 \mathrm{ml})$ using the methods of extraction and radioimmunoassay previously reported by Mondain-Monval et al. (1977), with the following modifications. The two steroids were separated on columns of Sephadex LH-20 in benzene-ethanol $(90: 10 \mathrm{v} / \mathrm{v})$ and eluted with $4.7 \mathrm{ml}$ of the same solution. Progesterone was eluted in the 0.6-1.1 ml fraction and oestradiol-17 3 in the $2.9-4.7 \mathrm{ml}$ fraction. Aliquants $(50 \mu \mathrm{l}$ of the progesterone fraction and $500 \mu \mathrm{l}$ of the oestradiol fraction) were assayed in duplicate.

Androstenedione and testosterone concentrations were determined as described previously (Mondain-Monval et al., 1979).

All samples taken from a single animal were assayed within a single assay. Samples with high steroid concentrations were re-assayed after dilution. The intra-assay and inter-assay coefficients of variation are listed in Table 1. Assay recoveries are given in Table 2.

Table 1. Characteristics of the radioimmunoassays used for determinations of steroids in blue fox plasma

\begin{tabular}{|c|c|c|c|}
\hline & \multicolumn{2}{|c|}{ Coefficients of variation $(\%)$} & \multirow{2}{*}{$\begin{array}{l}\text { Limit of detection } \\
\qquad(\mathrm{pg} / \mathrm{ml})\end{array}$} \\
\hline & Intra-assay & Inter-assay & \\
\hline Oestradiol-17 $\beta$ & $7.8(n=10)$ & $11 \cdot 8(n=10)$ & 9 \\
\hline Progesterone & $9.9(n=8)$ & $13.4(n=8)$ & 300 \\
\hline Androstenedione & $8 \cdot 4(n=9)$ & $11 \cdot 7(n=9)$ & 30 \\
\hline Testosterone & $8.9(n=9)$ & $11 \cdot 8(n=9)$ & 20 \\
\hline
\end{tabular}


Table 2. Recoveries of known amounts of steroids added to a pool of plasma from ovariectomized blue foxes

\begin{tabular}{|c|c|c|c|c|}
\hline \multirow[b]{2}{*}{ Steroid } & \multirow[b]{2}{*}{$\begin{array}{c}\text { Plasma } \\
\text { vol. }(\mathrm{ml})\end{array}$} & \multirow[b]{2}{*}{$\begin{array}{c}\text { No. of } \\
\text { determinations }\end{array}$} & \multicolumn{2}{|c|}{ Progesterone (ng) } \\
\hline & & & Added & $\begin{array}{c}\text { Recovered } \\
(\text { mean } \pm \text { s.d. })\end{array}$ \\
\hline Oestradiol-17 $\beta$ & $\begin{array}{l}1 \\
1 \\
1 \\
1 \\
0.5\end{array}$ & $\begin{array}{l}4 \\
4 \\
4 \\
4 \\
5\end{array}$ & $\begin{array}{l}0 \\
37 \cdot 5 \\
75 \\
150 \\
300\end{array}$ & $\begin{array}{c}\text { N.D.* } \\
39.5 \pm 3 \cdot 8 \\
79.8 \pm 6 \cdot 7 \\
150.8 \pm 7 \cdot 2 \\
303.0 \pm 21.0\end{array}$ \\
\hline Progesterone & $\begin{array}{l}1 \\
1 \\
1 \\
1 \\
0.5\end{array}$ & $\begin{array}{l}4 \\
4 \\
4 \\
4 \\
5\end{array}$ & $\begin{array}{l}0 \\
1.25 \\
2.5 \\
5.0 \\
10.0\end{array}$ & $\begin{array}{r}0.2 \pm 0.06 \\
1.4 \pm 0.2 \\
3.0 \pm 0.2 \\
5.6 \pm 0.3 \\
11.2 \pm 0.3\end{array}$ \\
\hline Androstenedione & $\begin{array}{l}1 \\
1 \\
1 \\
0 \cdot 5\end{array}$ & $\begin{array}{l}4 \\
4 \\
4 \\
4\end{array}$ & $\begin{array}{r}0 \\
75 \\
125 \\
250\end{array}$ & $\begin{array}{c}\text { N.D.* } \\
62 \cdot 0 \pm 4 \cdot 0 \\
108 \cdot 6 \pm 11 \cdot 2 \\
222 \cdot 0 \pm 21 \cdot 0\end{array}$ \\
\hline Testosterone & $\begin{array}{l}1 \\
1 \\
1 \\
0 \cdot 5\end{array}$ & $\begin{array}{l}4 \\
4 \\
4 \\
4\end{array}$ & $\begin{array}{r}0 \\
50 \\
100 \\
200\end{array}$ & $\begin{array}{c}\text { N.D.* } \\
51.6 \pm 3.3 \\
97.6 \pm 6.0 \\
193.0 \pm 9.9\end{array}$ \\
\hline
\end{tabular}

*N.D. $=$ not detectable.

\section{Statistical analysis}

All means are reported as \pm s.d. Analysis of variance was used for statistical examination of the plasma concentrations of androstenedione; where there was no homogeneity of variance as determined by Bartlett's test, the data were converted to logarithms.

\section{Results}

\section{Luteinizing hormone $(\mathrm{LH})$}

A major preovulatory $\mathrm{LH}$ peak was detected in 9 of the vixens. The data from these vixens were pooled to give the overall profile of plasma LH shown in Text-fig. 2(b). The preovulatory LH peak ranged from 13.5 to $73.0 \mathrm{ng} / \mathrm{ml}$ with an average of $27.8 \pm 18.8 \mathrm{ng} / \mathrm{ml}$. After the peak value, plasma LH concentrations declined to a baseline level of $1.3 \pm 1.0 \mathrm{ng} / \mathrm{ml}$ within $48 \mathrm{~h}$. In most animals, plasma LH concentrations remained significantly elevated above baseline levels for 2 days.

In the overall profile (Text-fig. 2b), baseline LH concentrations on Days -20 to -1 before the LH peak ranged from 0.8 to $5.3 \mathrm{ng} / \mathrm{ml}$. The concept of a baseline LH level for the individual vixen during pro-oestrus is, however, misleading. Text-figure 3 illustrates the plasma LH profiles from 3 individual vixens, and shows that there are rises of $\mathrm{LH}$ ranging from $3 \cdot 1$ to $10.4 \mathrm{ng} / \mathrm{ml}$ during this period. In Vixen $84 \mathrm{~S}$ there appeared to be 4 pro-oestrous $\mathrm{LH}$ surges (range $4 \cdot 4-10 \mathrm{ng} / \mathrm{ml}$ ).

The study revealed a good correlation between the onset of the behavioural manifestations of oestrus and the major preovulatory LH surge. Sexual receptivity was observed in 3 of the vixens by $24 \mathrm{~h}$ after the LH peak, and in the other 6 by $48 \mathrm{~h}$. All 9 vixens were mated 48 or $72 \mathrm{~h}$ after the LH peak and 8 of the animals conceived. 

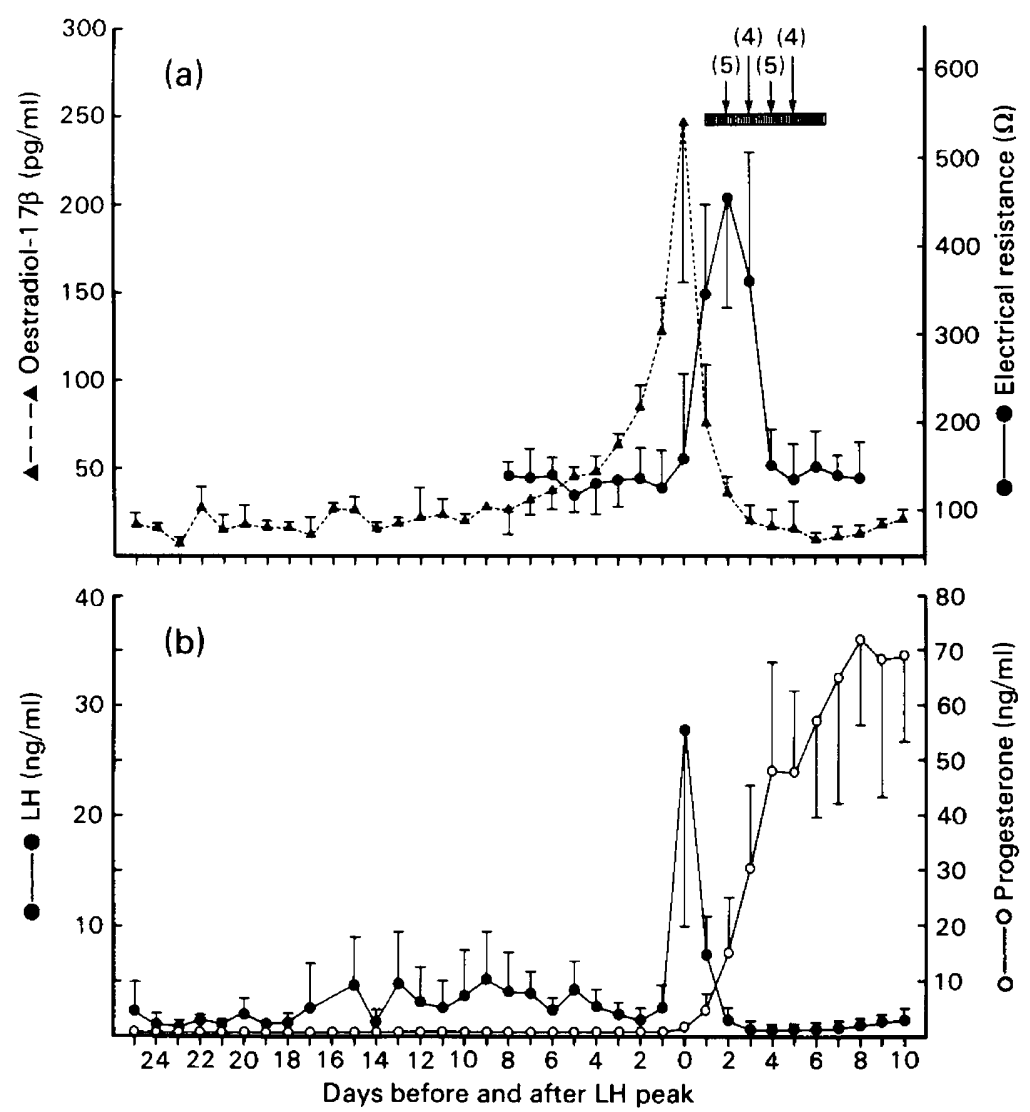

Text-fig. 2. The electrical resistance in the vaginal tract and plasma concentration of oestradiol-173, LH and progesterone in 9 blue fox vixens during pro-oestrus and oestrus. The shaded bar in (a) represents oestrus. All the vixens were mated (arrows) twice. Values are mean \pm s.d.

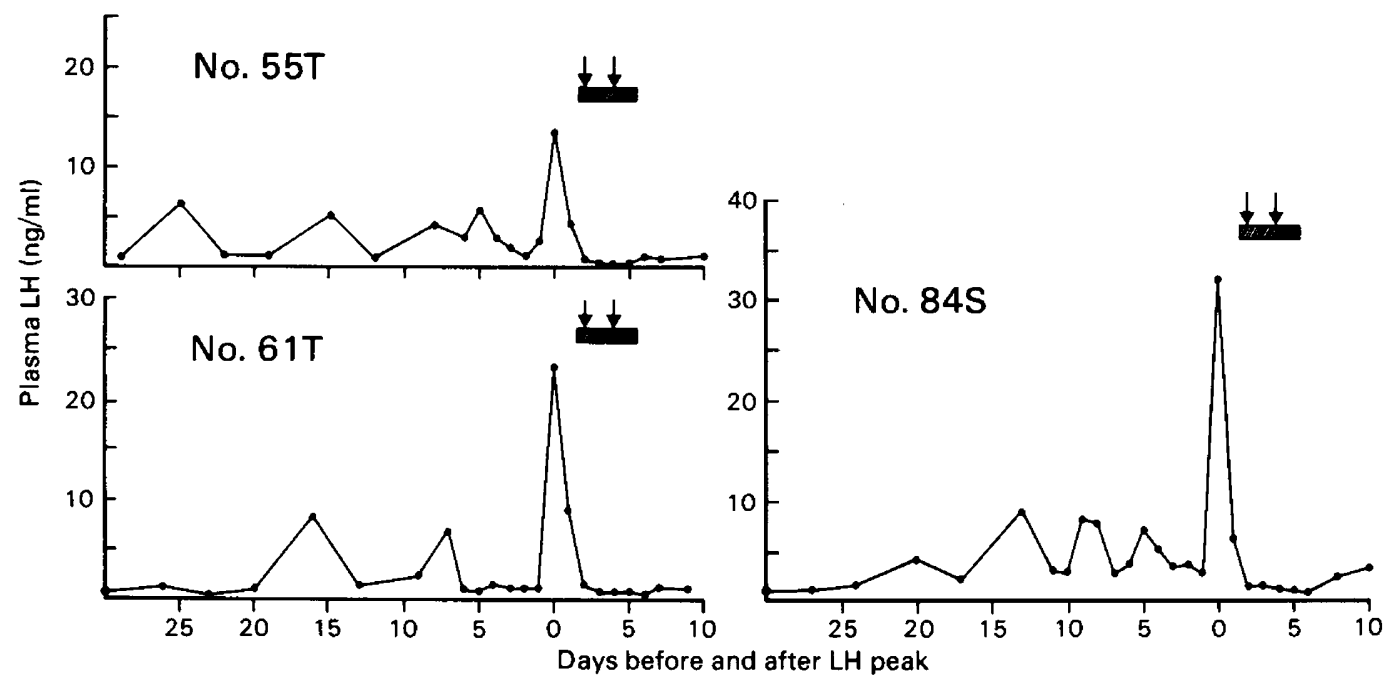

Text-fig. 3. Plasma levels of $\mathrm{LH}$ in 3 blue fox vixens during pro-oestrus. The shaded bars represent the oestrous period, and the arrows indicate the days of mating. 


\section{Oestradiol-17 $\beta$}

Plasma concentrations of oestradiol-17 (Text-fig. 2a) showed small daily variations, range 9$40 \mathrm{pg} / \mathrm{ml}$, during most of the pro-oestrous period. However, 4-6 days before the preovulatory LH peak, plasma oestrogen concentrations increased significantly and the maximum oestradiol value coincided regularly with the LH peak, i.e. 1-2 days before the onset of oestrus. In all the vixens the oestradiol-17 $\beta$ peak was well defined, with maximum concentrations ranging from 124 to 373 $\mathrm{pg} / \mathrm{ml}$. After the concentrations of oestradiol had reached a maximum, a rapid decline was observed and within 2-3 days plasma concentrations had reached values of $<50 \mathrm{pg} / \mathrm{ml}$, typical of those during pro-oestrus. Oestradiol levels were always low when there were no clinical signs of oestrus.

\section{Progesterone}

Plasma concentrations of progesterone (Text-fig. 2b) measured 1 day before the major preovulatory LH peak were consistently low $(<0.8 \mathrm{ng} / \mathrm{ml}$ plasma). The values increased significantly coincident with the LH peak and were always elevated above baseline levels $(4-40 \mathrm{ng} / \mathrm{ml})$ at the first mating. Plasma progesterone levels then rose steeply during oestrus and attained levels of $23-83 \mathrm{ng} / \mathrm{ml}$ when the vixens went out of heat.

\section{Androstenedione}

Plasma concentrations of androstenedione (Text-fig. 4a) remained nearly constant between 30 and 20 days before the $\mathrm{LH}$ peak, the mean value during this period $(188 \pm 46 \mathrm{pg} / \mathrm{ml}, n=9)$ being approximately the same as that observed after the LH peak $(158 \pm 66 \mathrm{pg} / \mathrm{ml}, n=9)$. Between Day -20 and the $\mathrm{LH}$ peak the mean value was significantly higher $(445 \pm 133 \mathrm{pg} / \mathrm{ml}, n=9, \mathrm{~F}(2 \cdot 24)=$ $18.2, P<0.01)$. In all the vixens, peak androstenedione concentrations coincided with the oestradiol-17 $\beta$ peak, maximum values ranging from 805 to $1879 \mathrm{pg} / \mathrm{ml}(1173 \pm 501 \mathrm{pg} / \mathrm{ml})$.

\section{Testosterone}

During pro-oestrus and oestrus, the fluctuations in the secretion of testosterone (Text-fig. $4 \mathrm{~b}$ ) were similar to those of androstenedione. The values were, however, significantly lower than those of androstenedione, averaging $154 \pm 105 \mathrm{pg} / \mathrm{ml}$ during the final 20 days before the $\mathrm{LH}$ peak. In the majority of vixens, the peak testosterone concentration coincided with the oestradiol-17 $\beta$ peak, while in 1 vixen it occurred 1 day afterwards. Maximum concentrations ranged from 328 to 501 $\mathrm{pg} / \mathrm{ml}$.

\section{Electrical resistance of the vaginal tract}

As shown in Text-fig. 2(a), the electrical resistance of the vaginal tract in the blue fox displayed a characteristic profile during the oestrous period. Values increased from $126 \pm 43 \Omega 1$ day before the oestradiol-17 $\beta$ peak to a maximum of $454 \pm 130 \Omega 2$ days after the peak. In most of the animals, the electrical resistance reached a peak on the first day of sexual receptivity. Individual differences were observed in the duration of the period of high electrical resistance (range 1-3 days). Values were always low $(<200 \Omega)$ as sexual receptivity declined. All the vixens were mated twice during the decline phase of the resistance profile, i.e. during the period 2-6 days after the LH peak.

Correlations between hormone concentrations, electrical resistance of the vaginal tract, oestrus and mating

Peak concentrations of $\mathrm{LH}$, oestradiol and androgens in general occurred 1-2 days before the first day of oestrus (Text-figs $2 a, 2 b \& 4$ ). The onset of oestrus came at a time when plasma concen- 


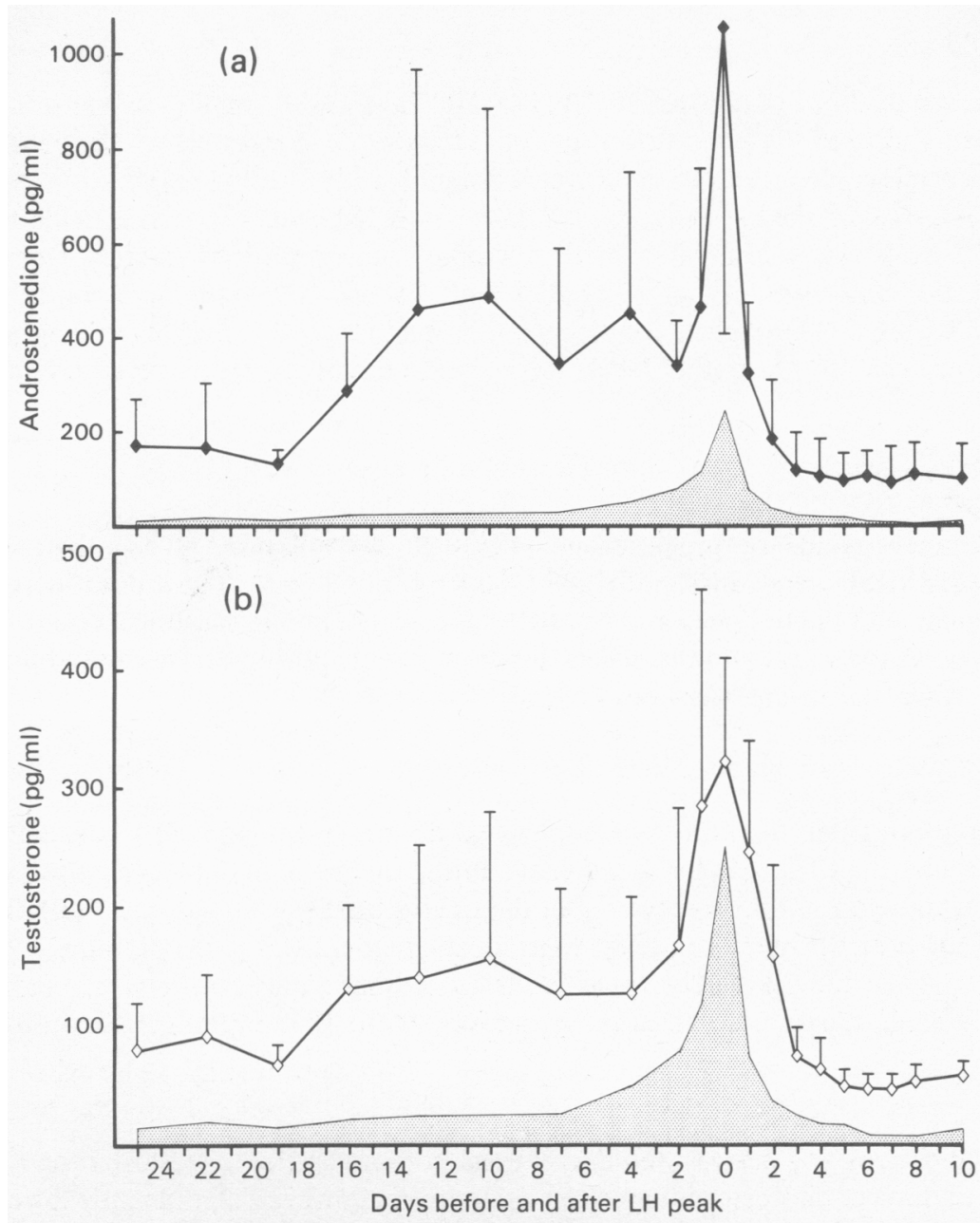

Text-fig. 4. Mean \pm s.d. plasma concentrations of (a) androstenedione and (b) testosterone in 9 blue fox vixens during pro-oestrus. The stippled areas represent the corresponding mean plasma concentrations of oestradiol- $17 \beta$ on the same scale.

trations of progesterone were increasing while those of oestradiol and LH were declining. The highest values of electrical resistance were generally recorded $24-48 \mathrm{~h}$ after the oestradiol-17 $\beta$ peak (Text-fig. 2a). Text-figure 2(a) indicates that the optimal time for mating occurs during the decline phase of resistance, and the mating programme used in the present study produced satisfactory conceptions.

\section{Discussion}

An interesting finding in this study was the observation of rises in plasma $\mathrm{LH}$ concentration that occurred during pro-oestrus in most of the vixens. Due to the variability of onset of these elevations, their presence was masked when an overall LH profile was plotted (Text-fig. 2b). Recent studies suggest that these pro-oestrous rises are in fact more frequent and of greater magnitude (up to 38 $\mathrm{ng} / \mathrm{ml}$ ) than those reported in the present study, but of short duration and therefore may easily be missed (unpublished data). In the ewe, Goodman, Reichert, Legan, Ryan \& Karsch (1981) sug- 
gested that the increase in tonic LH secretion is a stimulus for the preovulatory rise in plasma oestradiol concentration. This may also be the case in the fox.

The LH peak varied in magnitude from 13.5 to $73.0 \mathrm{ng} / \mathrm{ml}$, and the total plasma $\mathrm{LH}$ surge extended over a $24-72-\mathrm{h}$ period. It is probable that $\mathrm{LH}$ levels remain maximally elevated for only a few hours, and that the great variations observed in this study are a reflection of the relatively infrequent blood sampling regimen. The levels and duration of the major LH surge in the blue fox (1-3 days) are similar to those observed in the dog (2-4 days) (Concannon, Hansel \& Visek, 1975; Wildt, Chakraborty, Panco \& Seager, 1978). This was not unexpected since taxonomically the fox is a fairly close relative of the dog. The prolonged elevation of plasma $\mathrm{LH}$ above baseline values in canine species is comparable to that occurring in the rhesus monkey (Weick et al., 1973), but differs from the very long release in the mare (Geschwind, Dewey, Hughes, Evans \& Stabenfeldt, 1975), and from the brief release recorded in the rat, rabbit, hamster, ewe and cow (see Concannon et al., 1975 , for references).

Five of the blue fox vixens were mated on the 2 nd and the 4 th days and 4 on the $3 \mathrm{rd}$ and the 5 th days after the LH peak, indicating a distinct relationship between the LH peak and the onset of oestrus in the fox. In the bitch, on the other hand, the LH surge can occur at various times during the final 3 days of pro-oestrus and the first 5 days of oestrus (Concannon, Hansel \& McEntee, 1977; Wildt et al., 1978). No precise data appear to be available on the interval between the LH peak and ovulation in the blue fox, but in the silver fox it has been stated that most ovulations occur on the lst or 2nd day of oestrus (Johansson, 1941; Pearson \& Enders, 1943). In the bitch the majority of ovulations $(77.2 \%$ ) occur $24-72 \mathrm{~h}$ after the $\mathrm{LH}$ peak, and $93.5 \%$ of the follicles show morphological evidence of ovulation $96 \mathrm{~h}$ after the LH peak (Wildt et al., 1978). However, in the rat, ewe, sow, cow, monkey and human female the corresponding interval varies between 12 and $40 \mathrm{~h}$ (Niswender, Roche, Foster \& Midgley, 1968; Monroe, Rebar, Gay \& Midgley, 1969; Niswender, Reichert \& Zimmerman, 1970; Yussman \& Taymor, 1970; Swanson \& Hafs, 1971; Weick et al., 1973). Thus one of the unique aspects of canine endocrinology appears to be the prolonged duration of the interval between the LH peak and ovulation.

The demonstration of a well-defined oestradiol-17 $\beta$ peak with maximal plasma concentrations of about $245 \mathrm{pg} / \mathrm{ml}$ is similar to that reported by Møller et al. (1980). From the present data, it appears that there is a clearcut correlation between the preovulatory oestradiol-17 $\beta$ peak and the $\mathrm{LH}$ peak. This indicates that the major $\mathrm{LH}$ release, as in other species, is triggered by oestrogen secretion. However, the coincidence of the oestradiol peak and LH peak in the blue fox is decidedly different from the relationship seen in the bitch in which the oestradiol peak precedes the LH peak by 1-2 days (Concannon et al., 1975).

It is probable that the preovulatory follicles are the major source of the two androgens measured in this study and of oestradiol-17 $\beta$, since the concentrations of all three hormones decreased to low levels at the time of ovulation. Aromatization of androstenedione is the main pathway for the biosynthesis of oestrogen in the canine ovary (Aakvaag \& Eik-Nes, 1965). If androstenedione is an obligatory intermediate in the biosynthesis of oestradiol in the blue fox, the relatively large plasma androgen concentrations observed before ovulation may be purely a leakage phenomenon rather than a requirement for physiological events of the oestrous cycle.

In the red fox, androstenedione is thought to play a role in ovulation or the initiation of luteinization (Mondain-Monval et al., 1979). It is also possible that the two androgens function as additional regulators of gonadotrophin secretion in the periovulatory period (Pant, 1977). Baird, Swanston \& McNeilly (1981) suggested that the LH surge stimulates a large increase in the secretion of thecal androgens which accumulate within the follicle and then inhibit aromatase activity and eventually all follicular steroid secretion (Hillier, Boogaard, Reichert \& Van Haa, 1980).

The measurements of vaginal electrical resistance confirm previous observations (Møller \& Frøysedal, 1980; Møller, 1980). The present results indicate that precise recording of electrical resistance alone may allow conclusions to be drawn about the hormonal changes during the pre- 
ovulatory period. The hormone responsible for the changes in the vaginal tract is thought to be oestradiol. Cycle changes in the secretion of oestrogens are known to be reflected in the histology of the vaginal epithelium in the red fox (Mondain-Monval et al., 1977), and it is assumed that this cyclicity is reflected in the electrical properties of the vaginal tract. There is a delay of $1-2$ days between changes in plasma oestradiol concentrations and corresponding changes in vaginal electrical resistance. The decline phase of electrical resistance is clearly the optimum time for mating or insemination of blue fox vixens. It is essential to take serial measurements of resistance rather than attempting to rely on single readings since there are great individual variations in the height and duration of the resistance profile. Contamination of the vaginal tract with urine will also lead to misleading measurements.

The vaginal resistance profile recorded in canine species contrasts markedly with that observed in cows, pigs and sheep (Leidl \& Stolla, 1976). In sheep, the lowest values are observed during oestrus, whereas in the bitch (Klötzer, 1974) and in the blue and silver fox (Møller, 1980) the highest levels of resistance are recorded at this time. Leidl \& Stolla (1976) assumed that the blood in the vaginal secretion of the bitch was responsible for the incresae in electrical resistance, but blood is not present in the vaginal secretion of the fox.

The increase in progesterone concentration occurring coincident with the LH peak suggests that the LH peak induces preovulatory luteinization with resultant progesterone secretion. It is apparent from earlier studies that the ripe preovulatory follicles of the fox contain active luteal tissue (Pearson \& Enders, 1943; Møller, 1974b). The demonstration of a distinct increase in plasma progesterone concentrations before the onset of oestrus indicates that progesterone may be able to elicit copulatory behaviour in oestrogen-primed vixens (Møller et al., 1980). However, daily observations of sexual behaviour throughout pro-oestrus and oestrus in a large number of blue fox vixens have shown that the development of oestrous behaviour is not stereotyped, so further investigation is clearly warranted.

We thank Dr G. D. Niswender for the LH antiserum and Dr L. E. Reichert for the ovine LH and canine pituitary standard.

\section{References}

Aakvaag, A. \& Eik-Nes, K.B. (1965) Metabolism in vivo of steroids in the canine ovary. Biochim. biophys. Acta 111, 273-285.

Baird, D.T., Swanston, I.A. \& McNeilly, A.S. (1981) Relationship between LH, FSH and prolactin concentration and the secretion of androgens and estrogens by the preovulatory follicle in the ewe. Biol. Reprod. 24, 1013-1025.

Bonnin, M., Mondain-Monval, M. \& Dutourné B. (1978) Oestrogen and progesterone concentrations in peripheral blood in pregnant red foxes (Vulpes vulpes). J. Reprod. Fert. 54, 37-41.

Concannon, P.W., Hansel, W. \& Visek, W.J. (1975) The ovarian cycle of the bitch: plasma estrogen, LH and progesterone. Biol. Reprod. 13, 112-121.

Concannon, P.W., Hansel, W. \& McEntee, K. (1977) Changes in $\mathbf{L H}$, progesterone and sexual behavior associated with preovulatory luteinization in the bitch. Biol. Reprod. 17, 604-613.

Geschwind, I.I., Dewey, R., Hughes, J.P., Evans, J.W. \& Stabenfeldt, G.H. (1975) Plasma LH levels in the mare during the oestrous cycle. J. Reprod. Fert., Suppl. 23, 207-212.

Goodman, R.L., Reichert, L.E., Jr, Legan, S.J., Ryan,
K.D. \& Karsch, F.J. (1981) Role of gonadotropins and progesterone in determining the preovulatory estradiol rise in the ewe. Biol. Reprod. 25, 134-142.

Hillier, S.G., Boogaard, A.M.J., Reichert, L.E. \& Van Haa, E.V. (1980) Intra-ovarian sex hormone interaction of follicular maturation: aromatisation of androgens by human granulosa cells in vitro. J. clin. Endocr. Metab. 50, 640-647.

Johansson, I. (1941) Oestrus and mating in silver fox. Annls Agric. Coll. Sweden 9, 239-263.

Klötzer, I. (1974) Untersuchungen über den elektrischen Widerstand des Vaginalschleimes der Hündin. Kleintierpraxis 19, 125-133.

Leidl, W. \& Stolla, R. (1976) Measurement of electrical resistance of the vaginal mucus as an aid for heat detection. Theriogenology 6, 237-246.

Metzger, E., Freytag, R. \& Leidl, W. (1972) An instrument for testing the vaginal mucus for electric conductivity in the determination of oestrus in bovines. Zuchthygiene 7, 56-61.

Moller, O.M. (1973) Progesterone concentrations in the peripheral plasma of the blue fox (Alopex lagopus) during pregnancy and the oestrous cycle. J. Endocr. 59, 429-437. 
Moller, O.M. (1974a) Effects of ovariectomy on the plasma progesterone and maintenance of gestation in the blue fox, Alopex lagopus. J. Reprod. Fert. 37, 141143.

Moller, O.M. (1974b) The fine structure of the lutein cells in the blue fox (Alopex lagopus) with special reference to the secretory activity during pregnancy. Cell Tiss. Res. 149, 61-79.

Møiler, O.M. (1980) Measurement of electrical resistance of the vaginal tract to determine the optimum time to mate blue fox, silver fox and racoon dog. Norsk Pelsdyrblad 54, 591-595.

Meller, O.M. \& Frøysedal, F. (1980) Measurement of electrical resistance of the vaginal smear/mucous membrane in the blue fox (Alopex lagopus) and the silver fox (Vulpes argenteus) as an aid for heat detection. Proc. 2nd Int. Congr. Furbearing Anim., Copenhagen, No. 11, pp. 1-6.

Moller, O.M., Aursje, J.M. \& Sjaastad, Ø.V. (1980) Oestradiol-17 $\beta$ concentrations in the peripheral plasma of the blue fox (Alopex lagopus) around oestrus. Acta vet. scand. 21, 140-142.

Mondain-Monval, M., Dutourné, B., Bonnin, M., Canivenc, R. \& Scholler, R. (1977) Ovarian activity during the anoestrus and the reproductive season of the red fox (Vulpes vulpes L.). J. Steroid Biochem. 8, 761-769.

Mondain-Monval, M., Bonnin, M., Scholler, R. \& Canivenc, R. (1979) Androgens in peripheral blood of the red fox (Vulpes vulpes $L$.) during the reproductive season and the anoestrus. J. Steroid Biochem. 11, 1315-1322.

Mondain-Monval, M., Bonnin, M., Canivenc, R. \& Scholler, R. (1981) Activité LH plasmatique chez la renard roux (Vulpes vulpes L.). Résumé de communication. Path. Biol. Paris 29, 363-365.

Mondain-Monval, M., Bonnin, M., Canivenc, R. \& Scholler, R. (1984) Heterologous radioimmunoassay for fox $\mathbf{L H}$ : levels of $\mathbf{L H}$ during the reproductive season and the anoestrus in the red fox (Vulpes vulpes L.). Gen. comp. Endocr. (in press).
Monroe, S.E., Rebar, R.W., Gay, V.L. \& Midgley, A.R., Jr (1969) Radioimmunoassay determination of luteinizing hormone during the estrous cycle of the rat. Endocrinology 85, 720-724.

Nett, T.M., Akbar, A.M., Phemister, R.D., Holst, P.A., Reichert, L.E. \& Niswender, G.D. (1975) Levels of luteinizing hormone, estradiol and progesterone in serum during the estrous cycle and pregnancy in the beagle bitch. Proc. Soc. exp. Biol. Med. 148, 134-139.

Niswender, G.D., Roche, J.F., Foster, D.L. \& Midgley, A.R., Jr (1968) Radioimmunoassay of serum levels of luteinizing hormone during the cycle and early pregnancy in ewes. Proc. Soc. exp. Biol. Med. 129, 901904.

Niswender, G.D., Reichert, L.E., Jr \& Zimmerman, D.R. (1970) Radioimmunoassay of serum levels of luteinizing hormone throughout the estrous cycle in pigs. Endocrinology 87, 576-580.

Pant, H.C. (1977) Effect of androgens on concentrations of LH and FSH in the peripheral plasma of anoestrous ewes. J. Reprod. Fert. 50, 133-136.

Pearson, O.P. \& Enders, R.K. (1943) Ovulation, maturation and fertilization in the fox. Anat. Rec. 85, 69-83.

Swanson, L.W. \& Hafs, H.D. (1971) LH and prolactin in blood serum from estrus to ovulation in Holstein heifers. J. Anim. Sci. 33, 1038-i 041.

Weick, R.F., Dierschke, D.J., Karsch, F.J., Butler, W.R., Hotchkiss, J. \& Knobil, E. (1973) Preovulatory time courses of circulating gonadotropic and ovarian hormones in the rhesus monkey. Endocrinology 93 , 1140-1147.

Wildt, D.E., Chakraborty, P.K., Panco, W.B. \& Seager, S.W.J. (1978) Relationship of reproductive behavior, serum luteinizing hormone and time of ovulation in the bitch. Biol. Reprod. 18, 561-570.

Yussman, M.A. \& Taymor, M.L. (1970) Serum levels of follicle stimulating hormone and luteinizing hormone and of plasma progesterone related to ovulation by corpus luteum biopsy. J. clin. Endocr. Metab. 30, 396 399.

Received 1 March 1983 